\title{
RESISTANCE OR COMPLIANCE: READING DANIEL 1 AS A FAUX-HIDDEN TRANSCRIPT
}

\author{
Jonathan Redding \\ Nebraska Wesleyan University
}

\begin{abstract}
This article examines imperial and economic forces of colonisation surrounding post-exilic Israel, specifically the late Persian period (334-330 BCE) transitioning into the Hellenistic era (332-64 BCE), to do a suspicious reading of Daniel 1 as a text of imperial resistance. Using a paradigm constructed from elements of James Scott's theory of hidden transcripts from "Domination and the arts of resistance", Daniel 1 becomes a Hellenistic text capable of placating and appeasing as much as (or perhaps more than) opposing and resisting empire. This work emphasises suspicious tensions to examine socio-economic class structures in and around the composition of the book of Daniel to interpret Daniel 1 through a hermeneutic of suspicion with a focus on postcolonial theory.
\end{abstract}

Key words: Hebrew Bible; Hellenistic Judaism; Daniel; Hidden Transcript; Materialist; Postcolonial

Using a paradigm constructed from elements of James Scott's theory of hidden transcripts from Domination and the arts of resistance, Daniel 1 becomes a text capable of placating and appeasing as much as (or perhaps more than) opposing and resisting empire. John Goldingay regards reading potential ulterior motives behind Daniel's authorship and composition with suspicion:

A suspicious hermeneutic might view [Daniel's stories] as an upper class text designed to justify the authors' collaboration in exile. But they are a stories of a popular kind and may be designed to speak to Jews as an ethnic and religious minority more generally, the implicit argument being that if people like Daniel and his friends in their positions remained faithful and proved the faithfulness of God, ordinary people can do so too. (Goldingay, 1989:328)

Goldingay's observation articulates suspicious tensions well and promotes examining socio-economic class structures in and around the composition of Daniel to interpret Daniel 1 through a hermeneutic of suspicion. The article is in two sections. The first expands on the use of Scott's hidden transcript theory, then examines Israelite and Hellenistic histories through a Marxist economic lens. It then uses a socio-economic problematic to define the boundaries of economics and empire through which Daniel 1 may be read. The second section analyses and reads Daniel 1 to trace possible threads of compromise and accommodation underlying the tale, which, in turn, offers a renewed reading of Daniel 1 as a faux-hidden transcript. Conclusions present implications for further interpretation. 


\section{Section I - The economics of empire and written word}

Scholars widely accept characters and settings in Daniel as legendary (cf. Collins, 1993:2) and, thus, historically difficult to date. However, physical and historical evidence from certain eras makes it possible to construct generalised dates for Daniel. Literary features in Daniel like references to King Nebuchadnezzar II and historically murky characters like Darius the Mede and Belshazzar, ${ }^{1}$ pull Daniel back from a primarily Greek-Hellenistic perspective and orients the narrative some time during the neo-Babylonian empire (626-539 BCE) (Charpin, 2006:808). However, it is clear Daniel uses its late Babylonian backdrop metaphorically and replaces concurrent political leaders with long deceased and likely non-existent kings to convey its message. It is also clear that Daniel, like many Hebrew Bible/Old Testament books, alludes to or contains information that may be used to date a given text as older than its actual age (Lemche, 2001:293). Complexities and inconsistencies stemming from using a biblical text to date itself aside, many scholars agree upon the late Persian period into and during the Hellenistic empire (334-64 BCE) as the most probable timeframe in which the stories in Daniel were written. ${ }^{2}$

\section{The ongoing reality of the aristocracy}

This possible timeframe between the late Persian period and Hellenistic era grounds the book of Daniel in an era of tumult and military upheaval. The transition between Persian and Hellenistic empires trapped struggling Israelites within economic structures and systems. A thorough examination of the ancient economies from $334 \mathrm{BCE}$ to $64 \mathrm{BCE}$ is too great an undertaking for this essay, but an examination of class disparity and struggle in the late Persian and Hellenistic eras outlines influences that might have motivated the creation of faux-hidden transcripts. The advent of aristocratic empires in the ancient Near East shattered otherwise "totally unchanging" economic and social orders (Kautsky, 1997:4). Land ownership and exchange of surplus for monetary gain spurred aristocrats on to use peasants for personal financial gain, (Kautsky, 1997:4) thereby creating higher, wealthier classes and lower, proletariat classes.

Class separation during the decline of the Persian Empire and the rise of Hellenism divided the population into two groups: higher, aristocratic classes; and lower, peasantworker classes (Briant, 2006: 518-519). Géza Alföldy deems the "concept of class" as inappropriate for defining the Hellenistic-into-Roman imperial socio-economic systems, arguing the stratification was flexible and allowed some upward mobility (Alföldy, 1985:149). However, Alföldy's hesitation does not prevent him from admitting "various groups" met "these economic criteria" to a certain extent (Alföldy, 1985:149). Pierre Briant is comfortable speaking in such polar extremes and cites several instances in which King Darius himself "refers to the powerful and the poor, establishing himself as

See Grabbe, Lester. 1988. Another look at the Gestalt of Darius the Mede, CBQ 50; Koch, Klaus. 1980. Das Buch Daniel, EdF 144. Darmstadt: Wissenschaftliche Buchgesellschaft.

2 Cf. Smith-Christopher, Daniel. 1996. The Book of Daniel, NIB VII. Nashville, TN: Abingdon Press, 17-152; Collins, John. 1993. Daniel. Minneapolis, MN: Fortress; Seow, C.L, 2003. Daniel. Louisville, TN: John Knox; Portier-Young, Anathea. 2011. Apocalypse against empire. Grand Rapids, MI: William B. Eerdmans; among others. 
an arbitrator between the two categories" (Briant, 2006:518). Herodotus also notes Persian socio-economic rank as an extant and unremarkable fact:

When [Persians] meet each other in the street, there is a sign by which one may know if those who encounter are equals, and the sign is this: instead of greeting, they kiss one another on the mouth. If one of the two is a little humbler, they kiss on the cheek. If one of them is inferior in birth, he falls down and does obeisance to the other. Most of all they had hold in honor themselves, then those who dwell next to themselves, and then those next to them, and so on, so that there is progression in honor in relation to the distance. They hold least in honor those whose habitation is furthest from their own (Herodotus, tr. 1987:196).

Briant cites material possession and economic status as the deciding factor in determining rank, and J.K. Davies traces similar class differentiation as a socioeconomic phenomenon during the rise and fall of the Hellenistic influence. ${ }^{3}$ Davies argues early Hellenistic polis states depended on wealthy persons, or "aristocrats", for political, economic, and military control, meaning the presence and influence of a strong aristocratic class was one defining aspect of the era in which Daniel 1 may have been written.

John Kautsky also lobbies for reading with an awareness of a wealthy class, saying, "The aristocracy must be defined in terms of the economic and political role it plays in aristocratic empires for, unlike racial and ethnic characteristics, that role is in important respects the same in all aristocratic empires" (Kautsky, 1997:79). In short, aristocracy as an actualised concept remains static throughout history; details such as time, place, and political rule change, but the basic idea is treacherously timeless. Since the inception of "civilised" production-based empires and ruling constituencies, persons possessing monetary wealth have moulded and benefitted from economic systems, thereby granting themselves the title of nobility, freeing themselves from their own taxations, and granting themselves special rights based primarily on their ability to control land and the produce of said land. ${ }^{4}$

A dual-pronged approach to higher class exploitation of lower classes, known as direct and indirect exploitation, reveals a pertinent issue involving aristocracies and possible faux-hidden transcripts. According to G.E.M. de Ste Croix, "direct individual exploitation involved the master-slave relationship and other forms of unfree labour, and in wage-labour" (De Ste Croix, 1981:205). Forms of indirect collective exploitation "were applied by the state for the collective benefit of (mainly) the propertied class" at the expense of traders, merchants, shop keepers, independent artisans, and peasants (De Ste Croix, 1981:205). Indirect and collective exploitation did not occur at an "individual to individual" level; rather, according to de Ste Croix:

[indirect and collective exploitations] were exacted by the authority of the state (as defined above) from a whole community or from individuals; they would normally

Davies, J.K. 1984. Cultural, social, and economic features of the Hellenistic world. In Walbank, F.W., Astin, A.E., Frederiksen, M.W., and Ogilvie, R.M (eds.), The Cambridge ancient history vol. 7: The Hellenistic world, $2^{\text {nd }}$ ed. Cambridge: Cambridge University Press, 257-320.

$4 \quad$ Kautsky, The politics of aristocratic empires, 79. 
take one of three main forms: (1) taxation, in money or in kind; (2) military conscription; or (3) compulsory menial services (De Ste Croix, 1981:205).

Insight from de Ste Croix establishes a simple but weighty reality: wealthier persons and their connected groups took advantage of and benefitted from individuals and communities with lesser wealth; thus, aristocratic upper classes worked to keep said profitable systems in place.

From a colonising imperial perspective, persistence of economics-based class disparities depended on the practice of allowing conquered lands and peoples to maintain stability. For example, the changeover from Persian military control into Ptolemaic then Seleucid allowed native customs, laws, and forms of administration "to continue just as they had always done" throughout the empire (Grabbe, 1992:274). Persian practices differed from Ptolemaic-Seleucid Hellenistic rule, but, "because the Jews were allowed to continue living as they had done", there was "no indication of immediate change in the general circumstances of life in Judea" (Grabbe, 1992:275). Judean revolts did erupt during the rule of Antiochus IV (175-164 BCE), but only after temple vessels had been stolen, which reflects a period of relative stability despite changes in administrative powers (Grabbe, 1992:281). Previous changes made in and around Judean religious practice were limited to priestly office disputes over power and leadership. Evidence of conflicts among high ranking cultic officials takes centre stage in apocryphal writings chronicling the Maccabean revolt, but for the purposes of this study, the "top-down" political hierarchy merely solidifies evidence of class disparity. Minor revolts and aristocratic disputes aside, common Israelite and Judean citizens were oriented to behave as normal, in turn becoming pawns, subject to individuals and groups wielding financial and military power.

\section{Proliferation of ideas and ideologies}

Another socio-economic and cultural reality central to this exercise, is a result of connections between wealth, literacy, and the proliferation of ideas and ideologies. Returning to the earliest eras of the ancient Near East and into the latter days of scriptural composition, literacy and the ability to read and/or write was more than a luxury: it was a direct means to power and control. Thus, scribes and persons capable of writing and instructing other persons to write, had direct links to (and were often members of) the aristocracy, or, at the very least, literate persons working as government functionaries and mechanisms (Redford, 1992: 369-374).

The inception, evolution, and use of literature in the ancient Near East and Hellenistic era revolutionised cultic and political practices. Literacy in ancient Israel is a contentious scholarly issue, but Donald Redford articulates well the tensions surrounding notions of widespread illiteracy and recent archeological findings:

[T] he paltry few hundred ostraca and handful of seals and bullae that have come to light have, under no circumstances, given grounds to believe in a "literate" society in ancient Israel. Far more written material has come to light from Ptolemaic Egypt; but to call Egyptian society of the second century B.C. "literate" would give a 
misleading impression. The mere fact that some of the Hebrews could ${ }^{5}$ have written down bell-lettristic compositions does not mean that they did in fact do so. (Redford, 1992:304).

Redford is certainly not alone in making sound but conjectured assertions about the importance and scarcity of literature and literacy in the later phases of biblical Israel's lifespan. H. Vanstiphout argues writing was "the single most important cultural contribution" from the ancient Near East, going as far to say this statement "cannot be weakened by repetition" (Vanstiphout. 2006:2181-2196). Vanstiphout's assessment and study of writing, yields another crucial link between aristocracy and literacy: palace, temple, and local government structures had a great need for scribes as they required "specialised services" (Vanstiphout, 2006:2188). Thus, government structures and ruling class groups had direct access to writing and the creation of literature, and likely used these connections to control the proliferation of particular ideologies throughout the empire.

Elite priestly classes in the ancient Near East leading into the final years of the Persian Empire redefined the potential of literacy and propagation of ideas. As religion was written down, "a new situation arises since the priest has privileged access to the sacred texts of which he is the custodian and prime interpreter" (Goody, 1986:16-17). Mediation between priests and written religious texts gave aristocrats a unique link to the divine. Persons able to read and write became "gate-keepers of ideas", and, despite the diffusion of teaching methods and techniques, ideological content remained largely under the control of a specific subset of the population (Goody, 1986:17). Beginning with ancient Egypt and continuing into post-exilic Israel and its surrounding cultures, effective control of literature and other forms of written communication gave state and religious powers exclusive authority over both elite and lower classes.

The Hellenistic period was marked by the multiplication of books and other forms of documentation throughout the empire into Hellenistic Egypt (Havelock, 1982:335). Hellenistic literacy was "high culture" and reflected aristocratic perspectives (Havelock, 1982:10-11). Advances in writing and literary works in this era had far-reaching effects, with the orthography of printed language in post-Hellenistic texts reflecting "phonetic decisions adopted by the Alexandrian scholars of the Hellenistic age" (Havelock, 1982:319). War and military upheaval spurred conquering forces on to create "effective means of control" to perpetuate ideologies loyal to ruling powers (Morgan, 1998:23). Thus, "literacy and literate education" provided an organic means by which a "culture could be identified and distributed and the ruling class could be defined" (Morgan, 1998:23). Acknowledging the reality of literature as a method of controlling information, ideologies, and, in turn, the general populous, makes the existence of faux-hidden transcripts possible. 


\section{Section II - The method: Created hidden transcripts and false truths as systems of control}

James Scott describes discourse created and espoused by a given ruling majority, which he labels "public transcript", as "the open interaction between subordinates and those who dominate" (Scott, 1990: 2). Despite apparent widespread and uniform acceptance of public transcripts, Scott argues subordinate groups create "discourse that occurs 'offstage', beyond direct observation by power holders", known as "hidden transcripts" (Scott, 1990:4). Hidden transcripts exist outside public discourse and hide in plain sight, and subordinate groups wear "masks" constructed according to stereotypes and mainstream rituals to avoid confrontation that may occur as a result of unveiling hidden transcripts (Scott, 1990:3). Persons wear such masks to survive and endure the rigours of subordination and to create space for creating their own narratives beyond the control and constraints of dominant forces.

Scott bolsters his hidden transcript mask theory by presenting a companion theory of public transcript masks:

If the weak have obvious and compelling reasons to seek refuge behind a mask when in the presence of power, the powerful have their own compelling reasons to adopt a mask in the presence of subordinates. Thus, for the powerful as well, there is typically a disparity between the public transcript expressed safely only offstage. The offstage transcript of elites is, like its counterpart among subordinates, derivative: it consists in those gestures and words that inflect, contradict, or confirm what appears in the public transcript (Scott, 1990:10).

In short, members of different strata wear distinctive masks for similar reasons: to hide their motives and protect their interests. Wealthy upper-class persons don veils to keep subservient lower-class members appeased and functioning, then switch faces when surrounded by fellow aristocrats to appease their peers. Lower-class persons wear masks to pacify their "masters", supervisors, and other relevant aristocrats. Among members of their class, they wear masks akin to their actual selves, constructed according to personal and communal narratives.

Scott writes his hidden transcription and mask theories with an awareness of potential manipulation and exploitation, noting that persons in power want to control all information, including stories and motives created by persons under aristocratic authority (Scott, 1990:73). Scott cites and summarises John Gaventa's theory of false consciousness to argue that those in power supervise hidden narratives by creating fauxhidden transcripts 6 to propagate "a culture of defeat and nonparticipation" (Scott,

6 Cf. Gaventa, John. 1980. Power and powerlessness: Quiescence and rebellion in an Appalachian valley. Oxford: Oxford University Press, 22: “As A develops power, A prevails over B in decision-making arenas in the allocation of resources and values within the political system. If A prevails consistently, then A may accumulate surplus resources and values which may be allocated towards the construction of barriers around the decision-making arenas, i.e. towards the development of a mobilization of bias, as in the second dimension of power. The consistent prevalence of $\mathrm{A}$ in the decision-making arenas plus the thwarting of challenges to that prevalence may allow A further power to invest in the development of dominant images, legitimations, of beliefs about A's power through control, for instance, of the media or other socialization institutions. The power of A to prevail in the first dimension increases the power to affect B's actions in the second dimension, and increases the power to affect B's conceptions in the third." 
1990:73). Furthermore, wealthy persons and power brokers control public and private rhetoric at an ideological level by securing "the active consent of subordinate groups to the social arrangement that reproduce their subordination" (Scott, 1990:73). Scott is quick to critique such ideological control that those in power might wield, citing (without significant evidence) that opposition by lower classes against aristocrats under capitalism and feudalism throughout history, discounts unilateral application of Gaventa's theory (Scott, 1990:74).

Scott's counter argument against higher classes manipulating lower classes through faux-hidden transcripts is insufficient. Historical evidence of faux-hidden transcripts is difficult to cite, given the heavily interpretative move necessary to read a text as having a purpose opposed to the one it seemingly purports. Scott's opposition does not mean that stories like Daniel 1 lack the threads necessary to unravel historical readings of resistance and opposition; tugging such threads makes space for expanded interpretations.

\section{Section III - Hidden transcripts and privilege: Reading Daniel 1 alongside empire}

John Collins reads Daniel 1:1-2 as "a general introduction" recalling events leading to the exile, positioning characters in key roles, and setting the stage for the first chapter and entire book (Collins, 1993:129). Collins' straightforward reading dovetails with Donna Fewell's reading of Daniel 1:1-2 as the hidden transcript author's method of reconstructing the concurrent public transcript (Fewell, 2003:119). However, under a suspicious lens, the first two verses shift. First, the chapter begins without questioning the current political situation, which is problematic; throughout the Bible, Nebuchadnezzar symbolises the unwavering reality of empire. Collins addresses dating issues around v. 1 and Nebuchadnezzar laying siege to Jerusalem during King Jehoiakim's reign, saying the presented chronology "cannot be reconciled with any plausible reconstruction of the course of events" (Collins, 1993:131). He then takes a more direct route in theorising about the text's historical inconsistency, saying Daniel was clearly written during the time of Antiochus Epiphanes, and that the writer(s) used long-past settings to give Daniel 1 both historical flexibility and contemporary resonance (Collins, 1984:87-90).

The text's unquestioning certainty of empire is also unsettling. Inconsistent chronology and the use of figures much older than the book's composition date make Nebuchadnezzar, the conquering ruling force, and Jehoiakim, the overtaken force, filler characters. Underlying these mismatched monarchs is Daniel's divinely ensured monotonous certainty. According to v. 2, as Adonai ${ }^{7}$ wills, one king replaces another. Jehoiakim first appears in the biblical text in 2 Kings 23 as a puppet king installed by Pharaoh Neco, put on the throne to ensure tribute payment to the conquering Egyptians (Albertz, tr. 1994:232-236). Jehoiakim's reign was marked by conscripted and wagefree labour (Jer. 22:13), and was held in such low esteem that Jeremiah urges readers not to mourn or lament Jehoiakim's death (Jer. 22:18-19). 
These opening verses construct a hierarchy with Adonai at the top, Nebuchadnezzar next (by the deity's hand), and everything else waiting to be arranged. Numerous scriptural citations confirm Jehoiakim's negative notoriety among biblical writers and editors (2 Kings 24; 2 Chron. 36:5, 8; Jer. 26; 36:26; 52:2 among others), so one could argue that Daniel's likely post-exilic audience would have celebrated Jehoiakim's ousting. However, Jehoiakim's replacement, Nebuchadnezzar, had an equally negative reputation. Tension amplified with Adonai as the orchestrator organising the process, sending a clear message: Nebuchadnezzar is king because God wanted it to be so. Simply put, the deity Daniel's readers worshipped and with whom they were aligned, established a gentile king and empire. ${ }^{8}$ The newly enthroned king took temple articles, items likely taken into exile from Jerusalem as religious remembrances, and made them commonplace, thereby making them a sign of victory over Israel and its god (Goldinay, 1989:329).

The king speaks and his wish or desire receives immediate resolution. Hellenistic kings operated with unquestioned power, issuing decrees and demanding expedient, if not immediate, results from subsidiaries. ${ }^{9}$ Bearing in mind Daniel's purported preHellenistic narrative setting, Babylonian economic systems were based on similar kingship hierarchies. ${ }^{10}$ The two economies, one standing within the text and the other behind it, present unchanging stability. On a textual level, the change in leadership is unremarkable despite the particular historical characteristics of the empires. Historically, the progression of time from pre-Assyrian to Hellenistic reflects the normalcy of empire with confident efficiency and inevitability (Joannés, 2000:63-75). Reading Daniel 1 as a faux-hidden transcript, the certainty of being under monarchical rule, limits what will unfold. One could argue the writers built the arena and inserted players to destroy the arena in the course of the book (Albertz, 1988), ${ }^{11}$ but Daniel 1 introduces the narrative without dissonance or dissent.

Vv. 3 and 4 perpetuate the acceptance of empire by describing the type of young persons the king wants; not just any random group will suffice. If the ideal readers are meant to read Nebuchadnezzar's edict with chagrin, and identify with the four young men, the foursome's aristocratic background becomes noteworthy. Though Nebuchadnezzar and his court had higher political, social, and economic status than

8 Amy Willis notes Daniel 1:2 and the lack of culpability projected onto the community as the reason for the deity's historical activity, saying: '[t]he focus of historical presentation is primarily on God's interaction, not with the community, but with the kings and empires. This history displays God's incomparability by revealing the deity's interactions with these world-historical powers." See Willis, Amy. 2010. Dissonance and the drama of divine sovereignty in the Book of Daniel. New York, NY: T\&T Clark, 58.

9 For a concise but complete overview of the role of kings in Hellenistic economic structures, see Aperghis, G.G. 2011. Jewish subjects and Seleukid kings: A case study of economic interaction. In Archibald, Zosia A., Davies, John K., and Gabrielsen, Vincent (eds.), The economies of Hellenistic societies, Third to First centuries BC. New York, NY: Oxford University Press, 19-41.

10 For an overview of Mesopotamia economic practices and structures relating to kingship, return to Charpin, Dominique. 2006. The history of ancient Mesopotamia: An overview. In Sasson, Jack (ed.), CANE. Peabody, MA: Hendrickson, 807-829.

11 Albertz, Rainer. 1988. Der Gott des Daniel. Stuttgart, Germany: Verlag Katholisches Bibelwerk. Though Albertz's work deals primarily with Dan. 4-6, he argues the book uses historically powerful kings and ancient kingdoms to circumvent their human power in place in God's divine intentions. Reading Dan. 1 as an introduction, the book makes Albertz's theory to the opening and throughout the book. 
Daniel, Hananiah, Mishael, and Azariah, v. 3 makes it clear that Daniel and his three Judahite comrades were members of an elite socio-economic stratum.

Words used to describe Nebuchadnezzar's requirements become a rote list and an exercise ad nauseam. He asks for physically pristine young Judahites, young men without blemish (me' $\hat{u} m$ ). Rainer Stahl argues the most crucial descriptors in Daniel 1 revolve around physical beauty and intellectual capability as the king's wish for the chosen to be aesthetically pleasing, is on par with their ability to perform undisclosed duties (Stahl, 1994:135-139). The word me'ûm and a derivative word with a similar meaning, mûm, ${ }^{12}$ appear throughout the Hebrew Bible referencing physical and cultic abnormalities. For example, Nebuchadnezzar's wishes echo Leviticus 21 and the requirements for becoming a priest and approaching the altar of YHWH. The text makes it clear that the four men are worthy of Israel's highest cultic service, which moves them away from common readers and closer to the aristocracy.

The group's ability to learn, read, and write, places them above potentially handsome farmers and good-looking artisans. From a socio-economic perspective, one could read v. 4 in a countdown format starting with what the king wants, increasing with each desired value, and peaking at literacy:
Daniel 1:4:
INTRO. yelādîm 'ášer
4. 'ên-bāhem kol-me'ûm wetôbê mar'eh
3. ûmaskîlîm bekol-hokmāh weyōd'ê da'at
2. ûmebînê maddā' wa'ăšer kōah bāhem la 'ămōd behêkal hammelek
1. ûlălammedām sēper ûlešôn kasdîm

By beginning the list with physical attributes then moving to intellectual capability, the sentence hides the men's most crucial feature in plain sight: above all else, they must be able to read and produce literature. Smith-Christopher notes literacy's importance here, saying:

Note that the assessment of their competence to serve in the king's palace is made before they have been trained, implying that they have something to offer the king's court, and that, therefore, their knowledge of Jewish language and culture is what the king is particularly interested in (Smith-Christopher, 1996:39).

The foursome's well-rounded skillset makes the group formidable in many settings and creates highly idealised caricatures of captive Judahites.

Daniel 1:5 straddles neutral observation and hatred-inducing realisation. Collins' brief and straightforward reading takes v. 5 as a simple but effective means of progressing the chapter's plot (Collins, 1993:139-140). Goldingay's use of A.L. Oppenheim's dated but relevant overview of ancient Near Eastern palaces in Ancient Mesopotamia: Portrait of a dead civilization adds the weight of economic and social

12 Textual notes from BHS indicate a qere in multiple manuscripts that replaces me'ûm with mûm; similar translations and text critical indecision allows me to read and understand the two words as slight variations of the same concept. See Goldingay, Daniel, 5 n.4b for further support. 
status: Daniel and his comrades' placement in the palace will grant them access to wealth and means beyond anything the common Judahite could ever obtain (Goldingay, 1989:17).

One could argue that Daniel should entirely reject the king's offer since Daniel is the key character in a book about imperial resistance. ${ }^{13}$ Daniel only requests a slightly different version of the king's plan, which brings Daniel and his friends closer to the king's throne. Read in isolation, v. 6 introduces Daniel with little fanfare; however, v. 3 and 6 illuminate each other. Daniel is either Israelite royalty, or a high-ranking noble, or both. Non-canonical historical documents support Daniel's nobility: Josephus (1958:262) confirms Daniel's upper-class status and describes him as King Sacchias' eldest son, making Daniel a member of the Israelite royalty. Daniel is arguably an Israelite prince, making the four men in Daniel 1 privileged citizens; they are given the opportunity to gain intimate and unfettered access to the king because of their extant status.

Nebuchadnezzar chooses his Israelite courtiers with class similarity and distinction in mind; it is very likely this Hellenistic recreation of the Babylonian king reflects intraclass loyalty. Wealthy ruling classes rarely experienced internal disagreement, but conflict was rife between landowners and financiers on one side and peasants, artisans, and slaves on the other (De Ste Croix, 1981:340). Ruling classes created, implemented, and enforced systems favouring themselves and other persons with above-subsistence means. Evidence also exists to support the claim that upper class leadership fabricated animosity between sections of the lower and poorer classes as swift and advantageous control methods (Friesen, 2008:19).

Class dynamics in Daniel 1:3-6 reveals threads for deconstructing anti-imperial sentiment. Aristocrats surround themselves with aristocrats, not for torture, but for the proliferation of ideas. By pulling Daniel and his friends into the king's inner circle, Nebuchadnezzar appeases potential upper-class readers and hearers, while the emphasis on the group's Judahite ethnicity, appeals to commoners. This arrangement of literary elements keeps the people from one end of the economic spectrum to the other satisfied, thereby promoting stability throughout the empire.

Babylonian courts used names to suit imperial needs, and the privilege of Daniel and his compatriots is demonstrated by receiving names. Temple slaves were often branded with the seal of the temple god or king, and other slaves and lower class members active in cultic and royal courts, were defined by their physical particularities, such as scars and height (Stol, 2006:485). Thus, Daniel bearing a Babylonian name may appear as a slight or degrading, but, in fact, receiving a royal name elevated his status from an obscure and unknown Judahite noble or temple slave to a welcomed member of the king's advisers. Naming, not a vague designation based on arbitrary physical attributes, is crucial to Scott's theories of domination and subordination. He uses the example of enslaved Africans in the American Southern states being forced to forgo their birth names in favour of given slave names. The fear and pain Scott associates with naming humiliation, is absent in Daniel's re-identification; instead, a capricious apprehension for food and drink takes centre stage.

13 This is not an uncommon trope throughout the Hebrew Bible: see 2 Sam.11 for Uriah the Hittite's solidarity with his fellow soldiers by rejecting David's repeated offers for Uriah to lie with his wife. 
Mark McEntire cites Daniel 1:11 and 1:19 and the reassertion of Hebrew names as the narrator's rejection of Babylonian names, corresponding "to the character's refusal to eat and drink like Babylonians" (McEntire, 2012:574-575). Based on McEntire's reading, the text may reject the names, but Daniel accepts the name, though he rejects the food and drink provisions. This is not to say Daniel accepts his foreign name, but his passivity creates literary tension. Daniel's ardent resolve against the food, amplifies the naming tension: the text does not imply Daniel and his friends kept their Hebrew names behind closed doors, àla hidden transcript, but Daniel 1 does provide a detailed look into Daniel's thoughts as he constructs an elaborate show of his rejection of provisions under the guise of Judahite purity laws.

Daniel 1:8-9 blurs Daniel's quasi-religious motives, presents Daniel and his deity as willing to cooperate with Babylonian governmental structures, and withholds Daniel's motives for opposing the king's food and wine. The word often translated as "defile himself"14 is yitgä'al, a hithpael imperfect form of $g \bar{a}$ 'al, understood in other scriptural writing as "cultic impurity" (Mal. 1:7; Isa. 59:3, and Lam. 4:14), or as "stain", with less religious connotation (Isa. 63:3). Hermeneutical lenses of resistance read Daniel's decision as an attempt to keep Torah law, but the text does not reveal what makes the food unacceptable; Torah's dietary laws are not openly violated by what the king offers and wine is not forbidden in the Torah.

The chief palace officer's role in v. 7-9 creates additional tensions. First, Daniel's allegiance with the officer lacks prior justification. Daniel's relationship with the officer is one of subservience: the reader meets Ashpenaz in Daniel 1:3 when he is responsible for finding and bringing people meeting the king's description to fulfill the king's command. He performs an overt act of power by giving Daniel a Babylonian name, which indicates Ashpenaz's higher standing in the royal hierarchy above Daniel. Daniel must do as Ashpenaz's instructs. But Daniel accepts as much as he rejects, which begs the question: What is Daniel's goal? Who is he trying to please?

Unlike Exodus 9:12 and Daniel 1:2, God's intervention in v. 9 fails. Perhaps the chief palace officer's act of compassion is not killing or physically harming Daniel, but the text is unclear as to what God's work in Daniel 1:9 accomplishes. Daniel's behaviour towards the chief's subordinate raises faux-hidden transcript tensions. Ashpenaz opposes Daniel's plan based on possible consequences for Ashpenaz but Daniel withholds Aspenaz's apprehensions from the agreeing subordinate; perhaps Daniel misleads this unnamed guard into complacency.

Ashpenaz's remarks are convenient for progressing the plot, but reveal another layer of Daniel's aristocratic privilege: the lives of Daniel and his friends are not in jeopardy. Regardless of motive, it is clear Daniel's life is never at risk before, during, or after the proceedings. If replicated, Daniel's "model" behavior could (and likely would) have placed non-aristocratic persons in legal jeopardy, or, at worst, life threatening situations. Perhaps Daniel's misleading ingenuity has a two-fold purpose: for lower-class citizens, it may inspire resistance that accommodates existing systems, placating dissatisfied persons and upholding the status quo; for upper-class members, it assures them that the ruling system operates in aristocratic favour.

14 See JPS, NRSV, RSV, and KJV. 
Since Daniel accepts vegetables and water from the king's provisions, he consumes provisions from the king's royal and cultic settings, which raises faux-hidden transcript tensions. Daniel does not seek "going without" and engaging in a hunger strike; he simply wants to eat the food that he wants to eat, not what is given to him. The health of Daniel and his friends is again not at risk, because the results of Daniel's plan will display the group's strength and physical capability.

Daniel's success continues in v. 15 as the plan accomplishes his goal and benefits the foursome. In the eras Daniel straddles, ranging from its literary Babylon to its concurrent Hellenistic environment, economic structures were historically known for overexerting working-class citizens to the benefit of wealthy land owners, royalty, noble persons, and their beneficiaries. The text never makes labour-related exploitation an issue: Daniel chooses what he will and will not eat with disregard for how the various foods and drinks are acquired.

Considering the ambiguity surrounding Daniel's rejection of the king's initial food, it is puzzling when God rewards the foursome with wisdom and the ability to write. Granting Daniel and his friends the abilities of reading and writing, bolsters them, confirming their status as elite members of the royal nobility; they can now control the construction and flow of information and ideas. God distinguishes Daniel's gifts from the foursome with the peculiar nuance of understanding other-worldly events and happenings via dream vision discernment. The foursome entered the story with wealth and holding royal lineage, and as the narrative develops, they cement their aristocratic status through divine gifts. One could argue the group now has the tools and means necessary to make a defiant stand against the foreign king and his ruling government. However, as the final verses show, Daniel uses his access and skills for personal benefit and advancement.

Daniel's plan succeeds flawlessly, giving him and his companions direct access to the king. The chapter's conclusion is remarkable in its passivity: little changes from the opening verses - no Babylonian or Israelite characters lose anything or have anything significant taken from them. The king does not know about Daniel's dietary adjustments, nor does it seem the chief palace official is aware of his guard's insubordination. Daniel 1 concludes exactly as the king intended according to vv. 3 and 4: strong, able, and intelligent Israelites take advisory servant positions in the royal court.

Valeta notes the satisfaction of the king's initial request with apprehension:

Ironically, [the king] does not realize that the change in menu and the blessing of their God has enabled these noble Israelites to excel. The king rewards these heroes for being successful and faithful products of royal training, while the reader knows that the captives have creatively manipulated the king through a conspiracy with his servants to establish some autonomy. (Valeta, 2008:74; my italics)

Valeta is not alone in his interpretation of reading the foursome as valiant champions. ${ }^{15}$ While Daniel's actions took gall, labelling the group as "heroes" is excessive for two reasons. First, Daniel acts alone. Daniel 1 offers no insight into the thoughts, actions, and

15 See Smith-Christopher, Daniel; Collins, Daniel; Goldingay, Daniel; Portier-Young, Apocalypse against empire; and many others. 
motives of Hananiah, Mishael, and Azariah; the narrator only grants access into Daniel's mind. Thus, describing the silent three with laudatory words or praise overlooks their most obvious contribution to the narrative: passive acceptance. The friends remain quiet and do as Daniel wishes; he acts as a de facto leader without opposition or approval. Compliance implies the friends' acceptance, but one could remove the three from Daniel 1 and the story would change little, if at all. Possible messages of resistance become screenplays for solo abstinence as Daniel isolates himself without warrant and eliminates any possible dissent among his cohorts.

Second, the reader is pressed to discover what Daniel accomplished to warrant praise and admiration. The text withholds judgment regarding Daniel's choices and outcomes, and one can contend that the actualisation of God's gifts, indicates approval for Daniel's actions, but Daniel 1 offers no additional assessment. Suspicion haunts Daniel's "success", because the situation's outcome reflects active acceptance instead of passive resistance. Nebuchadnezzar praises the men for being exemplary students and, as Valeta says, excellent products of the royal education system. Chapter 1 concludes by telling the reader of Daniel's extensive tenure in the royal court, implying success, prosperity, and unconcealed connections to the heart of ancient Babylonian politics.

\section{Conclusion}

When questioning Daniel's author and intended audience, it is effortless to find narrative threads necessary to invert reading the chapter as a hidden transcript-style narrative of resistance. Daniel, the titular heroic figure, enters the story as an Israelite nobleman with nothing at stake or in jeopardy; he continues losing nothing and gaining political, social, literary, and supernatural prestige. The rewards and honours Daniel and his friends receive, placate lower class members into submission and appease aristocratic minds with hints of money, fame, and success. Historical importance and (scarcity of) literacy is crucial to reading Daniel 1 as a faux-hidden transcript. Daniel 1 is a product of its time, and, risking over-simplification, one can argue that Daniel's writers and editors were not members of a lower class, meaning they wrote for and among themselves.

Daniel 1 also makes Daniel a stand-in character for wealthy Israelite noblepersons under foreign control, and his friends become silent sycophants in the positions of the text's ideal subservient Israelite commoners: they do as their leader, Daniel, says, without hesitation or protest. The relationship between Daniel and the three becomes an administrative hierarchy that can be an example others may follow by addressing certain questions: How does a person of wealth and means remain in the upper class? Cultivate relationships with appropriate persons in power and amalgamate into their countenance. How does a non-aristocratic Israelite survive and thrive under the weight of foreign occupation? Trust your leaders; God blesses their decisions, and following them ensures a moderate and stable lifestyle. Further, this story can work as a contrived example of keeping lower classes appeased. Daniel includes Hananiah, Mishael, and Azariah enough to give them part of his success, but he is clearly superior. Thus, the story offers an image of giving working class members "just enough" to make them believe leadership has their best intentions in mind, while the overt reality enables those in power to cement their status. 
The chapter's use of God also supports the possibility of reading Daniel 1 as a fauxhidden transcript. V. 2 is straightforward in terms of God's role in Nebuchadnezzar's rise, thereby setting a precedence for what follows: God is in control. God follows Daniel's resolution to avoid the king's prescribed rations, but, according to the text, God is not the source of Daniel's resolve; Daniel alone devises the plan. Daniel ignores and sidesteps the response of the chief palace official after God orients him to Daniel's wishes. One could argue Daniel rebuffs God and follows his own procedures: Ashpenaz withdraws support, which may symbolise a warning from God or displeasure with Daniel's actions, but Daniel makes his own way. Despite Daniel's defiance, God blesses him with superior abilities designed to ensure Daniel's success in the king's court. God never speaks and is Daniel's pawn, put in place to facilitate avenues for Daniel's benefit.

Ambiguous characters like Daniel give readers pause while making audiences question motives and purposes behind traditionally historic figures. For example, rereading the "founding" of the United States from the perspective of indigenous persons killed and oppressed by European settlers, causes sharp reconsideration of American "heroes" like Christopher Columbus and Andrew Jackson (Zinn, 2003). Reading against the traditional interpretative grain continues the conversation begun by recent archeological finds and subsequent socio-economic realities of the ancient Near East and biblical Israel. Every hermeneutic has an agenda, and this article follows that trend through postcolonial readings and postmodern biblical study by seeking to expose dominant readings of the Bible that have become central to the cultural archive of Western thought (Horsley, 2013:241-260). In short, Daniel may be a heroic figure, but he may just as easily be something else entirely.

\section{BIBLIOGRAPHY}

Albertz, Rainer. 1988. Der Gott des Daniel. Stuttgart, Germany: Verlag Katholisches Bibelwerk.

Albertz, Rainer. 1994. A history of Israelite religion in the Old Testament period, vol. 1: From the beginning to the end of the monarchy [tr. John Bowden]. Louisville: Westminster John Knox.

Albertz, Rainer. 1994. A history of Israelite religion in the Old Testament period, vol. 2: From the exile to the Maccabees [tr. John Bowden]. Louisville: Westminster John Knox.

Alföldy, Géza. 1985. The social history of Rome [tr. Croom Helm]. Totowa, NJ: Barnes and Noble.

Aperghis, G.G. 2011. Jewish subjects and Seleukid kings: A case study of economic interaction. In Archibald, Z.A., Davies, J.K., Gabrielsen, V. (eds.), The economies of Hellenistic societies, Third to First Centuries BC. New York, NY: Oxford University Press, 19-41.

Azzoni, Annalisa. 2012. Betraying the text: Creation narratives in their and our context. In Berquist, J., and Hunt, A. (eds.), Focusing Biblical studies: the crucial nature of the Persian and Hellenistic period: Essays in Honor of Douglas A. Knight. New York: T\&T Clark, 83-91. 
Briant, Pierre. 2006. Social and legal institutions in Achaemenid Iran. In Sasson, Jack (ed.), CANE. Peabody, MA: Hendrickson Publishers, 518-519.

Charpin, Dominique. 2006. The history of ancient Mesopotamia: An overview. In Sasson, Jack (ed.), CANE. Peabody, MA: Hendrickson Publishers, 807-829. Collins, John. 1984. The apocalyptic imagination. New York, TN: Crossroad. Collins, John. 1993. Daniel. Minneapolis, MN: Fortress Press.

Davies, J.K. 1984. Cultural, social, and economic features of the Hellenistic world. In Walbank, F.W., Astin, A.E., Frederiksen, M.W., and Ogilvie, R.M. (eds.), The Cambridge ancient history vol. 7: The Hellenistic world, $2^{\text {nd }}$ ed. Cambridge: Cambridge University Press, 257-320.

De Ste Croix, G.E.M. 1981. The class struggle in the ancient Greek world. Ithaca, NY: Cornell University Press.

Elliger, Karl and Rudoplh, Willhelm. 2001. Biblia Hebraica Stuttgartensia. Germany: German Bible Society.

Fewell, Donna Nolan. 2003. The children of Israel: Reading the Bible for the sake of our children. Nashville, TN: Abingdon Press.

Fewell, Donna Nolan. 1988. Circle of sovereignty: A story of stories in Daniel 1-6. Sheffield: Almond Press.

Friesen, Steven. 2008. Injustice or God's will: Early Christian explanations of poverty. In Holman, Susan (ed.), Wealth and poverty in early church and society. Grand Rapids, MI: Baker Academic, 17-36.

Gaventa, John. 1980. Power and powerlessness: Quiescence and rebellion in an Appalachian valley. Oxford: Oxford University Press.

Goldingay, John. 1898. Daniel, WBC 30. Dallas, TX: Word Books.

Goody, Jack. 1986. The logic of writing and organization of society. Cambridge, UK: Cambridge University Press.

Gottwald, Norman. 1979. The tribes of Yahweh. Maryknoll, NY: Orbis Books. Grabbe, Lester. 1988. Another look at the gestalt of Darius the Mede, CBQ 50.

Grabbe, Lester. 1992. Judaism from Cyrus to Hadrian vol. 1. Minneapolis, MN: Fortress Press.

Havelock, Eric. 1982. The literate revolution in Greece and its cultural consequences. Princeton, NJ: Princeton University Press.

Herodotus. 1987. The History, [tr. David Grene]. Chicago, IL: The University of Chicago Press.

Holm, Tawny. 2013. Of courtiers and kings: The Biblical Daniel narratives and ancient story-collections. Winona Lake, In: Eisenbrauns.

Horsley, Richard. 2013. "It is more complicated": Reflections on some suggestive essays. In Boer, Roland (ed.), Postcolonialism and the Hebrew Bible: the next step. Atlanta, GA: Society of Biblical Literature, 241-260.

Joannés, Francis. 2000. Guerre et économie dans l'empire néo-babylonien. In Économie Antique: La guerre dans les économies antiques. France: HauteGaronne Conseil General.

Josephus. 1958. The Jewish Antiquities, Books IX-XI [tr. Ralph Marcus]. Cambridge, MA: Harvard University Press. 
Kautsky, John. 1997. The politics of aristocratic empires. New Brunswick, NJ: Transaction Publishers.

Kirkpatrick, Shane. 2005. Competing for honor: A social-scientific reading of Daniel 1-6. Boston, MA: Brill.

Koch, Klaus. 1980. Das Buch Daniel, EdF 144. Darmstadt: Wissenschaftliche Buchgesellschaft.

Lemche, Niels Peter. 2001. The Old Testament - A Hellenistic Book? In Grabbe, Lester (ed.) Did Moses speak Attic? Sheffield, England: Sheffield Academic Press, 287-318.

McEntire, Mark. 2012. The graying of God in Daniel 1-7, Review and Expositor 109: 569-579.

Morgan, Teresa. 1998. Literature education in the Hellenistic and Roman worlds. Cambridge, UK: Cambridge University Press.

Oliver, G.J. 2011. Mobility, society, and economy. In Archibald, Zosia A., Davies, John K., and Gabrielsen, Vincent (eds.), The economies of Hellenistic societies, Third to First Centuries BC. New York, NY: Oxford University Press, 345-367.

Pitt-Rivers, Julian. 1978. The fate of Shechum, or the politics of sex: Essay in the anthropology of the Mediterranean. Cambridge: Cambridge University Press.

Portier-Young, Anathea. 2011. Apocalypse against empire. Grand Rapids, MI: William B. Eerdmans Publishing Company.

Redford, Donald. 1992. Egypt, Canaan, and Israel in ancient times. Princeton, NJ: Princeton University Press.

Scott, James. 1990. Domination and the arts of resistance: Hidden transcripts. New Haven, CT: Yale University Press.

Seow, C.L. 2003. Daniel. Louisville, TN: John Knox Press.

Smith-Christopher, Daniel. 1996. The Book of Daniel, NIB VII. Nashville, TN: Abingdon Press, 17-152.

Stahl, Rainer. 1994. Von welt-engagement zu welt-überwindung: Theologische positionen im Danielbuch. The Netherlands: Kok Pharos Publishing House.

Stol, Marten. 2006. Private life in ancient Mesopotamia. In Sasson, Jack (ed.), CANE. Peabody, MA: Hendrickson Publishers, 485-501.

Valeta, David M. 2008. Lions and ovens and visions: A satirical reading of Daniel 1-6. Sheffield, England: Sheffield Phoenix Press.

Vanstiphout, H. 2006. Memory and literacy in ancient Western Asia. In Sasson, Jack (ed.), CANE. Peabody, MA: Hendrickson Publishers.

Von Rad, Gerhard. 1972. Genesis. Philadelphia, PA: The Westminster Press.

Waltke, Bruce K. and O’Conner, M. 1990. An introduction to Biblical Hebrew syntax. Winona Lake, IN: Eisenbrauns.

Wenham, Gordon. 1994. Genesis 16-50. Dallas, TX: Word Books.

Willis, Amy. 2010. Dissonance and the drama of divine sovereignty in the Book of Daniel. New York, NY: T\&T Clark.

Zinn, Howard. 2003. A people's history of the United States: 1492-Present. New York, NY: Harper Perennial. 